Article

\title{
Smart Sustainable City Roadmap as a Tool for Addressing Sustainability Challenges and Building Governance Capacity
}

\author{
Gabriela Viale Pereira ${ }^{1, *(1)}$ and Luiza Schuch de Azambuja ${ }^{2}(\mathbb{D}$ \\ 1 Department for E-Governance and Administration, Danube University Krems, \\ 3500 Krems an der Donau, Austria \\ 2 Ragnar Nurkse Department of Innovation and Governance, Tallinn University of Technology, \\ 12618 Tallinn, Estonia; Luiza.Schuch@taltech.ee \\ * Correspondence: gabriela.viale-pereira@donau-uni.ac.at
}

check for updates

Citation: Viale Pereira, G.; Schuch de Azambuja, L. Smart Sustainable City Roadmap as a Tool for Addressing Sustainability Challenges and Building Governance Capacity. Sustainability 2022, 14, 239. https:// doi.org/10.3390/su14010239

Academic Editors: J.

Ramon Gil-Garcia,

Mila Gasco-Hernandez and

Tzuhao Chen

Received: 26 November 2021

Accepted: 22 December 2021

Published: 27 December 2021

Publisher's Note: MDPI stays neutral with regard to jurisdictional claims in published maps and institutional affiliations.

Copyright: (c) 2021 by the authors. Licensee MDPI, Basel, Switzerland. This article is an open access article distributed under the terms and conditions of the Creative Commons Attribution (CC BY) license (https:// creativecommons.org/licenses/by/ $4.0 /)$.

\begin{abstract}
Building smart sustainable cities initiatives requires governance capacity, which is constantly challenged by a diversity of actors and the transformation towards a digital society; however, the process of identifying the conditions for building a smart sustainable city (SSC) is not straightforward. As an attempt to map the key governance conditions, the goal of this study is to suggest guidelines for the development of SSC initiatives in the format of a generic roadmap. This research applies design science research methodology and builds the roadmap based on identified antecedents that may hinder or facilitate the development of SSC initiatives from a systematic literature review and the analysis of key governance aspects from 12 smart city initiatives in Europe and Latin America. This paper builds its results through a four-step approach including: (1) defining the main concepts and dimensions within the smart sustainable city context; (2) identifying sustainability challenges for the development of smart sustainable city initiatives; (3) analysing key governance aspects from smart sustainable city initiatives; and (4) designing an actionable research-based roadmap and practical recommendations. The resulting roadmap contains 11 key governance conditions for developing strategies for smart sustainable city initiatives that were classified into three main phases: (1) planning; (2) implementing; and (3) adopting, monitoring, and evaluating. In terms of contribution, this research provides a tool to support the development of initiatives, addressing sustainability challenges and strengthening governance capacity to ensure the long-term impacts of smart sustainable cities.
\end{abstract}

Keywords: smart sustainable city; governance; sustainability challenges; governance capacity; roadmap; design science research

\section{Introduction}

Smart sustainable cities (SSC) characterise the progression on the application of digital technology and innovative solutions by the cities to address the needs of their populations and pursue sustainable socio-economic development. The urban development that drives SSC requires a strong capacity for public governance to support the planning, designing, and management of the ongoing transformations of the city, which are enabled by technological innovation [1]. The current literature highlights the need for understanding the complex process of developing smart sustainable city initiatives and addressing the insufficiency of tools to support stakeholders [2], the lack of strategic planning for initiatives, and the scarcity of a city agenda for guiding their implementation [3-6]. In addition, Sarv and Soe [7] have identified a knowledge gap between smart city theory and implementation from the perspective of an existing situation versus the related long-term strategy, and their results indicate that the current plan of a middle-sized European capital city differs from the goals set out in their smart city strategy.

A smart sustainable city is associated with the application of emerging technologies and digitalization of governments; however, the success of innovation in local government 
requires more than just the focus on technology [6,8], and should seek for a balance between three dimensions-city policy, city management and technology [7]. Additionally, because the aspects of a city are multidomain $[9,10]$, it requires a holistic strategy to become smart, connecting the main sustainability pillars (social, economic, and environmental), and addressing, for instance, the six dimensions of smart cities grouped by Giffinger [11] as follows: Smart Economy, Smart Mobility, Smart Governance, Smart Environment, Smart People and Smart Living. SSC have the potential for overcoming urban problems, and governance plays a key role in fostering sustainable development [12]; however, policymakers and smart city-related stakeholders lack research-based practical recommendations to support the planning and implementation of smart sustainable city initiatives and the definition of actionable long-term strategies towards sustainable development.

In order to bridge this gap and contribute to improving the governance capacity and understanding of the necessary aspects to develop SSC initiatives, this paper aims to answer the following research questions: What are the conditions to build smart sustainable cities initiatives to address sustainability challenges? As well as how to build local governance capacity for smart sustainable cities development?

One way to help the understanding and development of complex processes is the use of roadmaps. Road mapping is a flexible process for creating guidelines, which can be used to support different types of strategic aims such as, for instance, planning, supporting communication, and assessing projects [13]. Considering the benefits of roadmaps, this research intends to develop a smart sustainable city roadmap to serve as the basis for building local governance capacity and to guide the development of smart sustainable city initiatives by means of a design science research (DSR) methodology. The methodology followed a four-step approach including: (1) defining the main concepts and dimensions within the smart sustainable city context; (2) identifying sustainability challenges for the development of smart sustainable city initiatives; (3) analysing key governance aspects from smart sustainable city initiatives; and (4) designing an actionable research-based roadmap and practical recommendations.

The purpose of this paper is to advance the knowledge gap between smart sustainable city development and governance capacity, providing a path for urban planners and policymakers in addressing local governance and sustainability challenges as well as to provide recommendations for a future research agenda of SSC. This research seeks to define the phases and conditions for the development of SSC initiatives, considering governance and sustainability aspects, that will ultimately support cities in the process of becoming smart and sustainable. This paper is organised in four sections: 1 . Introduction; 2. Methodology; 3. Results and discussion (constructing and discussing the roadmap); and 4. Conclusions, implications, and limitations.

\subsection{Smart Sustainable Cities}

Smart sustainable cities are able to combine social, urban and technological aspects [14]. SSC symbolise the latest stages towards smart, digital, intelligent and sustainable systems and can be understood as a constant transformative process grounded on the collaboration of multiple stakeholders to pursue socio-economic development and to build human, technical and institutional capacities [15].

We build our understanding of SSC based on the conceptual framework proposed by Azambuja, Viale Pereira and Krimmer [16], including the three pillars of sustainability as balancing social, economic, and environmental dimensions to improve quality of life, in addition to the urban infrastructure dimension - which embodies the physical infrastructure and urban information and communications technology (ICT) in order to integrate all city aspects-and governance as the overarching dimension. The social dimension refers to the provision of city services to citizens, guaranteeing the quality of life, enhancing social participation, communication with citizens, education, decreasing the digital divide for reaching sustainability, etc. [15-17]. The economic dimension addresses challenges to the economic sustainability understood as "a city with a healthy, dynamic and responsible economy" [15]. 
The environmental dimension covers issues related to the protection and restoration of the natural environment, green buildings, energy savings, creating better spaces to live, and the adoption of ecological practices to protect the environment $[10,15,17,18]$.

A smart sustainable city is built upon the urban infrastructure-the physical infrastructure comprising roads, transportation, factories, buildings, subways and more, and ICT infrastructure- urban ICT assets comprising local area networks (LAN), servers, databases, software, open-source software, geographic information systems (GIS) and more [16]. The literature also distinguishes two domains of SSC projects: hard-the essential role of digital technology, and soft-technology understood as an enabler in education, culture, policy, and innovation [19]. According to Grimaldi and Fernandez [20], effective management of human capital leads to developing the "knowledge city" where the education sector substantially supports urban development, and policy implementation.

Finally, above all the mentioned dimensions, the governance dimension addresses the administrative capability to manage the cities' resources, people, policies and stakeholders, designing and implementing legal regulations, as well as providing compliance mechanisms and processes in a standardized and continuous manner $[16,17]$. This comprehensive model shows that a smart sustainable city extends the smart city concept. The SSC is an interdisciplinary concept that comprises different domains where technology serves as a means and not as a goal in itself. According to a recent study [21], the improvement of the quality of life of urban residents and the enhancement of city functioning can be achieved through activities covering the five dimensions suggested by Azambuja et al. [16]. Thus, those dimensions were used in this study to guide the identification and classification of potential challenges and enablers for the development of SSC.

\subsection{Governance of Smart Sustainable Cities}

Governance aspects are amongst the most important drivers for the development of cities [22]. Governance can be understood as the process of governing, which can be subdivided into different dimensions, such as structures and procedures [23]. It includes programmatic directions, budgetary and resource allocations, interactions with external actors as well as with different internal organizations, agencies, and departments [18]. These directions are usually described in formal institutions like policies, laws and regulations [23].

Governance is defined as the interaction and collaboration of different stakeholders in the decision-making process [24,25]. It represents the way cities organize internally with a strong focus on the empowerment of citizens, open government and collaboration, co-design and co-production, continuous improvement, acceptance and use of solutions, and the management of smart city stakeholders' motivations [26].

There are different governance paradigms, from the traditional and bureaucratic, to participatory and platform governance [27]. Speaking of urban governance, it is important to mention that it is not a matter of urban actors only, it requires actions from many actors [28], thus, the more appropriate paradigm for smart sustainable cities is one with a stronger focus on participation. In brief, participatory governance incorporates concepts of joint-up government, network governance and collaborative governance, including disclosure of information, citizen participation and monitoring [27]. Platform governance includes relationships of empowerment, coordination, value creation by citizens and collaboration [27].

In addition, smart governance can be defined as the use of collaborative governance and ICT-based tools to make better decisions by governments [29]. When bringing this concept to the smart sustainable city context, the focus is on the citizens' needs, making use of ICT to collect, integrate and analyse data to be used as input for decision making, engaging multi-stakeholders and using collaborative approaches [16]. The importance of governance is emphasized by the above-mentioned authors as the overarching component of SSC, providing the tools for ensuring socio-economic development and control over the environmental aspects of the city. Overall, smart sustainable city governance encompasses social norms, stakeholders, policies, partnerships, practices, data and information for 
balancing the sustainability pillars by making use of urban infrastructure and information communication technologies to govern the smart sustainable city $[16,17]$.

\subsection{Existing Smart (Sustainable) City Roadmaps}

Roadmaps are vision tools used for different purposes so as, for instance, to facilitate the communication between different stakeholders. Phaal et al. [30] analysed around 40 roadmaps in order to suggest a classification of roadmaps in terms of their format and purpose. Regarding their graphical format, we can find roadmaps bars, graphs, flow charts indicating objectives, actions and outcomes, layer(s), tables, pictorial demonstrations, or text. Concerning their purpose, the most common roadmaps are used for planning, including the planning of capability, knowledge, integration, products, strategy, long-term, programmes and processes [30]. Likewise, an SSC roadmap should be able to offer an overview of the goals and objectives of the transformation route of cities, and to indicate the necessary activities and milestones to achieve the vision of the city for becoming smart and sustainable [31]. The review on existing smart city-related roadmaps resulted in a list of available roadmaps and their respective phases as presented in Table 1.

Table 1. Main phases of existing smart-city related roadmaps.

\begin{tabular}{|c|c|c|}
\hline Roadmap & Roadmap Main Phases & Reference \\
\hline $\begin{array}{l}\text { An integrated service-device-technology } \\
\text { roadmap for smart city development }\end{array}$ & $\begin{array}{l}\text { 1-Preliminary activity } \\
\text { 2-Development activity } \\
\text { 3-Follow-up activity }\end{array}$ & [32] \\
\hline $\begin{array}{l}\text { European Platform for Intelligent Cities } \\
\text { (EPIC) Roadmap for Smart Cities }\end{array}$ & $\begin{array}{l}\text { 1-Vision phase } \\
\text { 2-Plan phase } \\
\text { 3-Design phase } \\
\text { 4-Build phase } \\
\text { 5-Deliver phase } \\
\text { 6-Operate phase }\end{array}$ & [33] \\
\hline SSC 6-step Transition Cycle & $\begin{array}{l}\text { 1-Set the vision for the SSC venture } \\
\text { 2-Identify SSC targets } \\
\text { 3-Achieve political cohesion } \\
\text { 4-Build a SSC } \\
\text { 5-Measure the city progress } \\
\text { 6-Ensure accountability and responsibility }\end{array}$ & {$[34]$} \\
\hline $\begin{array}{l}\text { Smart Sustainable City Transformation } \\
\text { Roadmap }\end{array}$ & $\begin{array}{l}\text { 1-City Vision } \\
\text { 2-City Readiness } \\
\text { 3-City Plan } \\
\text { 4-City Transformation } \\
\text { 5-Monitoring and Evaluation } \\
\text { 6-Sustain Change }\end{array}$ & [35] \\
\hline $\begin{array}{l}\text { Six-step pathway for the implementation } \\
\text { of responsive building envelope (RBEs) }\end{array}$ & $\begin{array}{l}\text { 1-Define purpose of response } \\
\text { 2-Identify scale and interdependency } \\
\text { 3-Identify functionality } \\
\text { 4-Identify trigger and control } \\
\text { 5-Identify interactions and requirements } \\
\text { 6-Identify technological solutions }\end{array}$ & [36] \\
\hline $\begin{array}{l}\text { Participatory Planning Approach Towards } \\
\text { Smart Sustainable City Development }\end{array}$ & $\begin{array}{l}\text { 1-Define problems and give them a } \\
\text { level of importance } \\
\text { 2-Identify goals for smart city development } \\
\text { 3-Recommend development plan for } \\
\text { short-term, medium-term, and long-term } \\
\text { planning by formulating projects on platform } \\
\text { of technology and innovations }\end{array}$ & [37] \\
\hline $\begin{array}{l}\text { Participatory planning for local } \\
\text { sustainability guided by the Sustainable } \\
\text { Development Goals (SDGs) }\end{array}$ & $\begin{array}{l}\text { 1-Localizing SDGs } \\
\text { 2-Data synthesis } \\
\text { 3-Analyzing possible futures } \\
\text { 4-Community engagement, objectives, } \\
\text { and validation }\end{array}$ & [38] \\
\hline
\end{tabular}

Source: own elaboration.

When analysing existing smart city roadmaps, most of them are focused on technology implementation, the so-called Technology Roadmap (TRM), as, for example, the roadmap 
suggested by Lee et al. [32]. Others are addressing just one dimension of SSC, and not providing a holistic perspective. To illustrate, the specific roadmap suggested by TaveresCachat et al. [36] is focused on the implementation of a responsive building envelope (RBE) in projects. Only a few attempts can be considered as a holistic SSC roadmap, such as the 6-step cycle for "becoming" a SSC, developed by the ITU-T Focus Group [34] and the transformation roadmap of Ibrahim et al. [35], which proposed a new approach grounded on the Theory of Change.

A novel model, recently created by Bibri and Krogstie [39] for data-driven SSC, offers a strategic guide for transformation towards sustainability in the context of big data [39]. Other roadmaps are focused on participatory planning towards SSC development [37] and on participatory planning guided by the Sustainable Development Goals (SGDs) [38], which demonstrates an approach to co-create a local sustainability plan using the SDGs for a rural community aiming to align bottom-up local needs with top-down global goals.

The analysis of existing roadmaps showed alignment with Lee et al. [32], who explained that the road mapping phases can be broadly grouped into three main stages: preliminary activity, development, and follow-up. Another observation is that the available tools do not highlight important governance aspects. For instance, there is no phase for establishing and managing the creation of partnerships, or a phase for integrating new systems and to provide training mechanisms, which are key enablers of SSC [40,41].

\section{Materials and Methods}

In this paper, we followed the design science research (DSR) methodology, a research paradigm focused on the development of an artefact to solve a problem [42], with a focus on the relevance and rigour cycles proposed by Hevner [43]. Artefacts can be constructs (vocabulary and symbols), models, methods and instantiations (implemented and prototype systems), being developed in a search process that collect existing applicable knowledge from the knowledge base (guaranteeing rigor to the research) with the purpose of developing a solution to a defined problem [42]. In this study, the overarching problem consists of identifying the conditions for implementing smart sustainable cities initiatives through a governance perspective and the artefact is the SSC roadmap.

As part of the design science research process, the first step of this study consists of a preliminary literature review on smart sustainable cities to identify the main concepts that can guide the development of the SSC roadmap (see Section 2.1). The second step includes a systematic literature review to identify drivers and barriers for the development of smart sustainable city initiatives (see Section 2.2). In a third step, 12 smart initiatives were analysed to identify important governance aspects based on secondary data (see Section 2.3). This empirical analysis was combined with the data gathered in the literature review and supports the evaluation of the research outcome through the complementary analysis of real-world cases, forming the relevance cycle approach. The smart sustainable city governance roadmap and the guidelines for strengthening smart sustainable city governance capacity, the fourth step of the method, constitutes the final contribution of this paper to the knowledge base as part of the rigor cycle. This step included a survey and a workshop to collect feedback from experts to improve the quality of the suggested roadmap (see Section 2.4).

The method and results of the four steps are sequentially presented below. Figure 1 illustrates an overview of those steps.

\subsection{Step 1: Defining the Main Concepts and Dimensions within the Smart Sustainable City Context}

Method. The literature background built the base for conducting the data collection and analysis. To describe the context, the research gap was identified and the most significant literature was documented that shapes the smart sustainable city topic, then a preliminary literature review was performed based on relevant references in the field and building on the preliminary framework developed by Azambuja et al. [16] (Section 1.1). To 
identify and document the important aspects pertaining to governance paradigms, smart governance models and their main components, and relevant references addressing the governance aspects of SSC were reviewed and summarized (Section 1.2). Finally, a review on existing smart city roadmaps supported the preliminary definition of generic roadmap phases to be contextualized in the smart sustainable city domain (Section 1.3).

Results. The outcomes of Step 1 are presented in Section 1.1. Table 2 contains our main definitions, which resulted from the literature review.

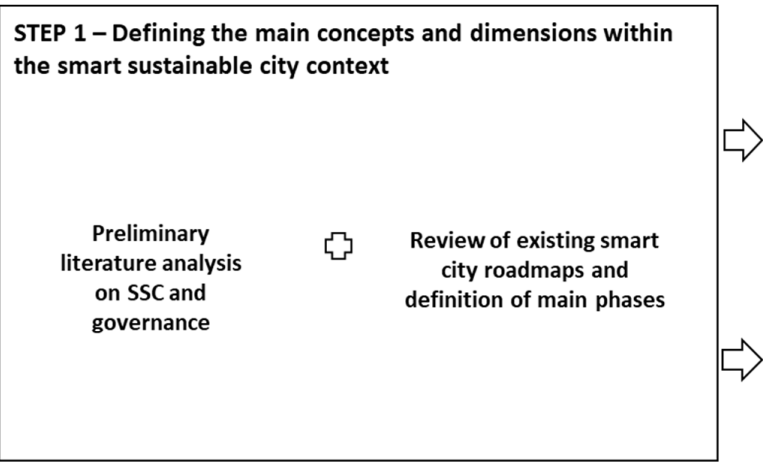

STEP 4 - Designing an actionable research-based roadmap and practical recommendations

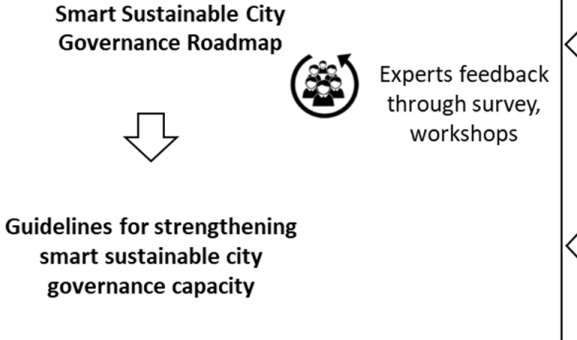

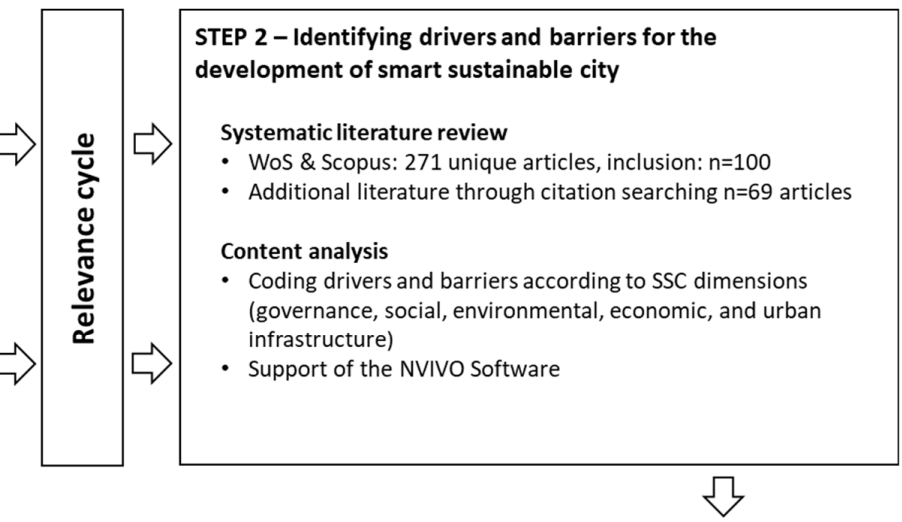

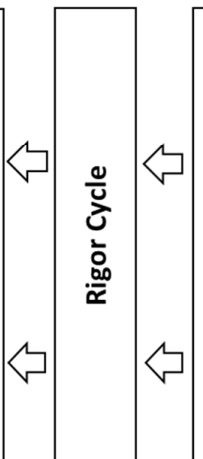

STEP 3 - Analysing key governance aspects from Smart Sustainable City Initiatives

Goal: Identifying governance aspects in different contexts

Analysis of secondary data collected in the context of the

CAP4CITY project

- 6 cases in Europe

- 6 cases in Latin America

Criteria for selection of cases

- Well-established, innovative, current and successful SSC initiatives covering different contexts

Figure 1. Overview of the four-step approach for developing a SSC roadmap.

Table 2. Main Concepts.

\begin{tabular}{ll}
\hline Key Concepts & Definition \\
\hline & Smart sustainable city can be defined as a territory (urban and rural) in continuous transformation, \\
& enabled by digital technology and innovation, stakeholder engagement and collaboration, \\
constructing human, institutional and technical capacities to solve problems and create new \\
development opportunities, to raise and maintain the quality of life in communities, and pursuing \\
sustainable development.
\end{tabular}

Governance plays a key role in balancing the social, economic, and environmental dimensions of sustainable development and the use of the urban infrastructure, as well as the information and communication technologies to connect the elements of a region towards the development of

SSC Governance sustainable and smart cities, communities, or territories. Ultimately, the governance of a SCC includes the definition and realization of locally appropriate paths to the development of smart solutions and the management of long-term relationships with stakeholders within and across government, business and societal sectors including citizen participation and co-decision-making in public affairs.

SSC Roadmap A smart sustainable city roadmap is usually comprised of the following main phases: planning SSC initiatives (defining purpose, vision, plan, targets, etc.); implementing SSC initiatives (designing, building, implementing, integrating); adopting, monitoring, and evaluating initiatives (monitoring and assessing, communicating, and sustaining). 


\subsection{Step 2: Identifying Sustainability Challenges for the Development of Smart Sustainable City Initiatives}

Method. The identification of main drivers and barriers for the development of smart sustainable cities was performed through a systematic literature review approach based on the PRISMA 2020 Statement [44] and the five-step method for data analysis proposed by Wolfswinkel, Furtmueller and Wilderom [45]. The first step was dedicated to defining the research plan, the inclusion and exclusion criteria. The second step was the search of relevant studies for review undertaken in May 2019 using Scopus and Web of Science. The query string used in the databases was: (("smart sustainable cit") OR ("sustainable smart cit") OR ("smart and sustainable cit" ) OR ("sustainable and smart cit") OR ("smart sustainability")), resulting in 271 unique records (the asterisk is used to retrieve variations of the term "city"). The full text of 204 eligible articles were first analysed, resulting in 100 eligible articles. An additional 69 publications were added for a better understanding of the SSC development process following the forward and backward method [45,46], resulting in 169 records. Using the NVIVO Software, the drivers and barriers were coded according to the SSC dimensions (governance, social, environmental, economic, and urban infrastructure). A total of 57 drivers and 63 barriers were found in the analysis of the 169 papers, mentioned, respectively, by 149 and 109 records. The results of the systematic literature review, which included 169 papers, are detailed in [47]. Combining the drivers and barriers from the social, economic, environmental, and urban infrastructure dimensions and translating those results into the context of the roadmap development, we defined 30 challenges of smart sustainable city development. Finally, the governance conditions included in the roadmap emerged from 118 papers that mentioned at least one governance driver or barrier.

Results. The literature review showed that there is still a lack of studies interrelating all smart sustainable city domains. Approximately 20\% out of the 169 analysed papers addressed SSC in a holistic way, mentioning social, economic, environmental, governance, and infrastructure aspects. The dimension that accounted for more drivers and barriers was the governance domain, followed by urban infrastructure. Among the 169 analysed papers, $118(70 \%)$ indicated a driver or barrier of the governance dimension, $103(61 \%)$ of the urban infrastructure dimension, $76(45 \%)$ of the environmental dimension, 63 papers $(37 \%)$ of the social dimension, whereas 58 papers $(34 \%)$ mentioned a driver or barrier of the economic dimension. Based on the list of 57 drivers and 63 barriers, we defined 30 sustainability challenges that guided the SSC governance roadmap, as illustrated in Figure 2.

\subsection{Step 3 Analysing Key Governance Aspects from Smart Sustainable City Initiatives}

Method. Secondary data of initiatives from the CAP4CITY project (ERASMUS+ CAP4CITY Project on Strengthening Governance Capacity for Smart Sustainable Cities. Available at https:/ / www.cap4city.eu/home/ access on 19 November 2021) database was analysed to complement the results gathered from the literature. The criteria used for selecting the cities was defined by the CAP4CITY project partners. Each project partner selected local cases of well-established, innovative, current, and successful SSC initiatives covering different contexts, from Latin America and Europe. For the current study, six initiatives from Europe and six from Latin America were analysed. The instrument used to collect data and to describe the SSC related initiatives was based on the instrument designed by Estevez, Lopes and Janowski [15]. The focus of analysis was on the governance aspects including "who" participated in the initiative (stakeholders), the approach, and best practices (evidence) to consider when developing the SSC governance roadmap. 


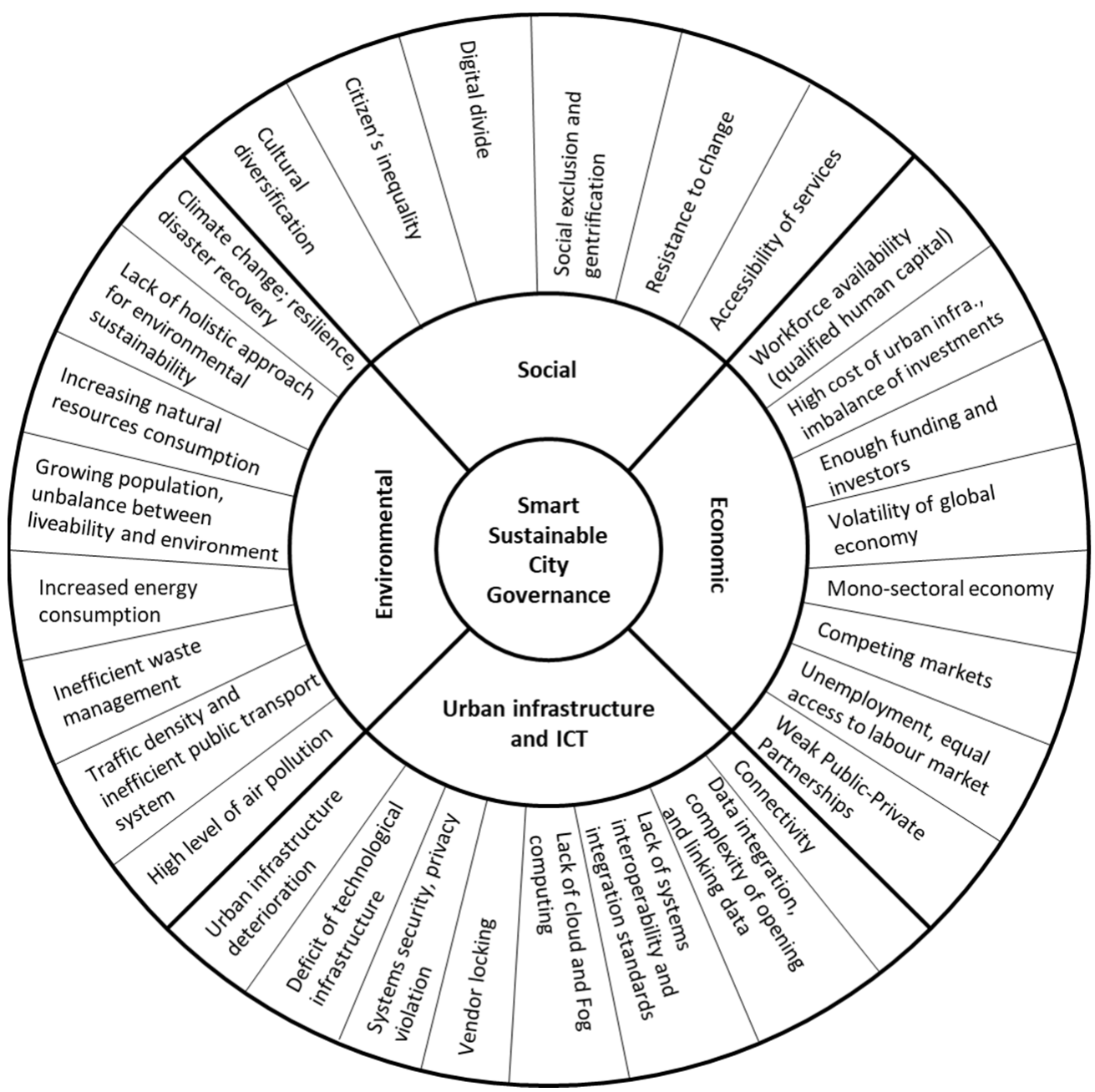

Figure 2. Sustainability challenges for SSC development. Source: own elaboration based on [47].

Results. Most of the cities engaged multiple stakeholders in their initiatives and promoted cooperation arrangements with the private sector, academic institutions and other cities and countries. The majority of initiatives had the government of the municipality as the lead organization; however, private companies, categorised as Industry, were the major partners developing assistance roles. Regarding the approach, top-down remains the most implemented approach. Bottom-up initiatives can be either citizen driven (in the cases of Santiago and Montevideo), or technology pushed (in the cases of Vienna, Copenhagen, Gdansk and Barcelona). In terms of the leading organization, most leading organizations were governmental ones, confirming one of the challenges found in the literature that the approach to SSC implementation is, in its majority, a top-down approach [48]. Table 3 summarizes the findings and presents some key aspects to consider for the design of the roadmap. 
Table 3. Overview of South American and European SSC initiatives.

\begin{tabular}{|c|c|c|c|}
\hline SSC Initiative & Approach & $\begin{array}{l}\text { Stakeholders }(\mathrm{L}=\text { Leader } \\
\text { P = Partner })\end{array}$ & Evidence/Best Practice for the Roadmap \\
\hline Vienna & Bottom-up; Top-down & $\begin{array}{c}\text { Government: } 2 \mathrm{~L} 15 \mathrm{P} \\
\text { Industry: } 3 \mathrm{P} \\
\text { Academia: } 6 \mathrm{P} \\
\text { Non-governmental } \\
\text { organization (NGO): } 3 \mathrm{P}\end{array}$ & $\begin{array}{c}\text { Strategy definition; monitoring and assessment } \\
\text { process; cooperation between science, public and } \\
\text { private sectors; living labs }\end{array}$ \\
\hline Copenhagen & Bottom-up; Top-down & $\begin{array}{l}\text { Government: } 1 \text { L } 2 \text { P } \\
\text { Industry: } 1 \text { P Academia: } 2 \text { P }\end{array}$ & $\begin{array}{l}\text { Integrated city data exchange; energy insight } \\
\text { allowing households and business to see how } \\
\text { much energy they use }\end{array}$ \\
\hline Tallinn & Top-down & $\begin{array}{l}\text { Government: } 1 \text { P } \\
\text { Academia: } 1 \mathrm{~L} 1 \mathrm{P}\end{array}$ & $\begin{array}{l}\text { Environmentally friendly and smart automated } \\
\text { public transport }\end{array}$ \\
\hline Helsinki & Top-down & $\begin{array}{c}\text { Industry: } 2 \mathrm{P} \\
\text { Academia: } 1 \mathrm{~L} 1 \mathrm{P}\end{array}$ & $\begin{array}{l}\text { Innovative public transport; research on the } \\
\text { applicability or usefulness of self-driving buses } \\
\text { for last mile transport }\end{array}$ \\
\hline Gdansk & Bottom-up & $\begin{array}{c}\text { Industry: } 1 \text { L } 14 \text { P } \\
\text { Academia: } 7 \text { PNGO: } 5 \text { P }\end{array}$ & $\begin{array}{l}\text { Integration and coordination platform for urban } \\
\text { systems to build applications across urban } \\
\text { systems; methodologies and tools for creating } \\
\text { real-time collaborative applications }\end{array}$ \\
\hline Barcelona & Bottom-up; Top-down & $\begin{array}{l}\text { Government: } 2 \text { L } 10 \mathrm{P} \\
\text { Industry: } 12 \mathrm{P} \\
\text { Academia: } 5 \mathrm{P} \\
\text { NGO: } 1 \mathrm{~L} 10 \mathrm{P}\end{array}$ & $\begin{array}{l}\text { Strategy definition; new municipal government } \\
\text { data model; CityOS; clear definition of roles and } \\
\text { responsibilities; Chief Data Officer } \\
\text { (CDO) position }\end{array}$ \\
\hline Buenos Aires & Top-down & $\begin{array}{l}\text { Government: } 1 \text { L } 2 \text { P } \\
\text { Industry: } 2 \mathrm{P}\end{array}$ & $\begin{array}{l}\text { New ways of thinking about public transport; } \\
\text { public bicycle transport system individual and } \\
\text { free to local citizens with online registration }\end{array}$ \\
\hline Curitiba & Top-down & $\begin{array}{c}\text { Government: } 1 \mathrm{~L} 3 \mathrm{P} \\
\text { Industry: } 2 \mathrm{P} \\
\text { Academia: } 1 \mathrm{P}\end{array}$ & $\begin{array}{l}\text { Urban development oriented to public } \\
\text { transportation and resilience; } \\
\text { innovation ecosystem }\end{array}$ \\
\hline Santiago & Bottom-up & $\begin{array}{c}\text { Government: } 1 \text { L } 2 \text { P } \\
\text { Industry: } 1 \text { P } \\
\text { Academia: } 1 \text { PNGO: } 1 \text { L } 2 \text { P }\end{array}$ & $\begin{array}{l}\text { Exhibitions where companies, innovators, } \\
\text { municipalities, universities, and small and } \\
\text { medium enterprises (SMEs) participate, present } \\
\text { their products and SC services; work for the } \\
\text { development and massification of } \\
\text { technology in Chile }\end{array}$ \\
\hline Bogotá & Top-down & Government: $1 \mathrm{~L} 1 \mathrm{P}$ & $\begin{array}{c}\text { Connectivity deployment initiatives; digital } \\
\text { government consolidation actions; citizen } \\
\text { innovation initiatives based on ICT }\end{array}$ \\
\hline Panama City & Top-down & $\begin{array}{l}\text { Government: } 1 \text { L } 2 \text { P } \\
\text { Industry: } 1 \mathrm{~L} 1 \mathrm{P} \\
\text { Academia: } 1 \mathrm{P}\end{array}$ & $\begin{array}{l}\text { Observatory of performance of the information } \\
\text { technology (IT) sector, research and } \\
\text { development (R\&D) laboratory; instruments } \\
\text { capable of transcending governmental changes }\end{array}$ \\
\hline Montevideo & Bottom-up & $\begin{array}{l}\text { Government: } 3 \text { L } 3 \text { P } \\
\text { Industry: } 1 \mathrm{P} \\
\text { Academia: } 1 \mathrm{P} \\
\text { NGO: } 3 \text { L } 2 \mathrm{P}\end{array}$ & $\begin{array}{l}\text { Interventions and applications systems initiated } \\
\text { by citizens; availability of public open data } \\
\text { inspired the creation of public solutions }\end{array}$ \\
\hline
\end{tabular}

Source: own elaboration based on CAP4CITY project database (internal document)

\subsection{Step 4: Designing an Actionable Research-Based Roadmap and Practical Recommendations}

Method. The roadmap was created based on the key governance factors identified in Step 2 of the research design and the evidence collected from the initiatives in Step 3, which were combined and described as "conditions" to develop SSC. The first version of the roadmap was validated through two workshops in Bogota and Medellin, Colombia (organised by the CAP4CITY project) and through one online questionnaire following 
guidelines of Bradburn, Sudman, and Wansink [49]. The link was sent to the CAP4CITY project members, and 15 participants provided their feedback. Afterwards, a new version of the roadmap was proposed, which was presented and discussed in two workshops at international conferences (DG.O in June 2019 in Dubai and EGOV-CeDEM-ePart in September 2019 in San Benedetto del Tronto), attended by 15 and 10 participants, respectively [1]. Finally, another version of the roadmap was created and reviewed online by 11 experts from 8 countries (Argentina, Brazil, Chile, Colombia, Germany, Greece, Mexico and Spain) in June 2020. The previous versions of the roadmap provided the basis for the proposed SSC governance roadmap, which is described through phases, conditions, and steps in Section 3.

\section{Constructing and Discussing the Smart Sustainable City Governance Roadmap}

The resulting roadmap contains 11 key governance conditions for developing strategies for smart sustainable city initiatives that were classified into three main phases: (1) planning (preliminary activity); (2) implementing (development of initiatives); and (3) adopting, monitoring, and evaluating (follow-up). Each key condition is explained by some steps or recommendations; however, we highlight that the process of developing smart sustainable city initiatives follows a continuous and flexible approach, being comprised of non-specific key conditions that can be adapted according to the city context. Therefore, the linearity of the described conditions is a conceptual simplification. The roadmap is illustrated in Figure 3, and the key conditions are described below.

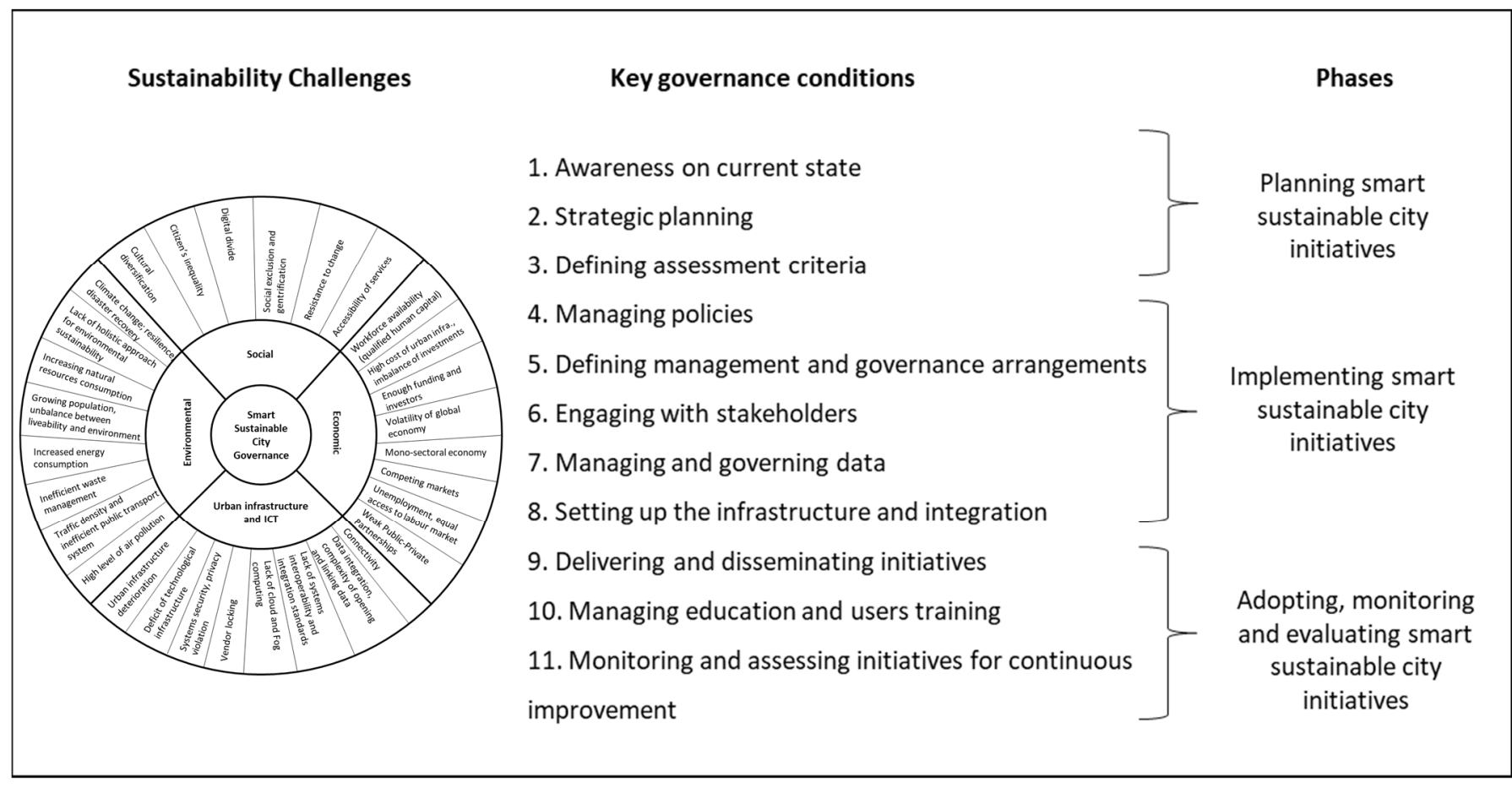

Figure 3. Smart Sustainable City Governance Roadmap. Source: own elaboration.

\subsection{Awareness on Current State}

The roadmapping key conditions vary according to the approach used, but two definitions are strongly recommended: the identification of the current position and the definition of the 'desired situation', resulting in a gap analysis that serves as input for planning actions. Awareness on the current state is achieved by the conditions: 1.1 define stakeholders, 1.2 understand the context, 1.3 needs assessment and 1.4 risk assessment and management. Defining stakeholders refers to the identification of internal and external actors, since involving groups of stakeholders in smart city projects is important for the success of the initiatives [50] and to guarantee a multidisciplinary background. Critically understanding 
the context includes the analysis of the political situation, societal problems, and local governance challenges; mapping of solutions and capabilities in place; understanding organizational structure, processes, and interactions; and external environmental scanning with stakeholders. Needs assessment reflects the perception of importance of the local needs, which may set the aims and values of the initiatives. Those are often related to social drivers, which include living aspects such as community needs and public provision of urban services (e.g., safety, culture, and recreation) $[8,48,51,52]$, innovative healthcare and sanitation facilities, education facilities to elevate the literacy rate and to generate workforces [53-59], as well as accessibility and social inclusion initiatives to minimize a digital divide. That aspect is also strongly related to the sustainable concept of smart cities, in which the needs of the present should be addressed without compromising the ability of future generations [60]. Finally, risk assessment and management relate to learning from previous errors and assessing possible risks [61], including technology, organisation and external environment-related risks [62].

\subsection{Strategic Planning}

One of the findings of this study relates to the importance of developing strategic planning for SSC implementation. Taking the examples of the analysed cases, Barcelona and Vienna have a defined smart city strategy, containing the city vision, plan of actions, assessment criteria, etc. Therefore, planning for the desired situation condition is achieved by the conditions: 2.1 develop a vision for smart sustainable city development, 2.2 plan human resources capacities, 2.3 plan infrastructure, 2.4 define a financial plan, 2.5 plan partnerships, and 2.6 seek for approval and commitment. Developing a vision for smart sustainable city development relates to setting the workplan and defining medium and long-term visions. Since the lack of capacity planning and lack of human capacity have been identified as barriers for SSC development, projects should be analysed thoroughly well before their initiation. Initiatives should have roles and responsibilities defined and documented to set expectations, including a leader responsible for promoting and monitoring the initiative's performance. Those aspects are to be addressed in the planning human resources capacities. Regarding the planning of infrastructure, this will vary depending on the context of application, since cities in more developed economies tend to have the basic infrastructure for implementing SSC in place while cities in developing economies may need to invest more in technology to implement such initiatives. It is also important to plan the strategies to integrate existing technologies [63].

Related to the economic challenges identified in the literature and case studies, defining a financial plan is necessary due to the high costs of urban infrastructure for SSC development (including both operational and maintenance). Therefore, prioritising investments to balance hard infrastructure (physical, hardware, sensors, systems) and soft infrastructure (capabilities) [64] is recommended, as well as seeking funding and investors through partnerships [15,23,48,65-69]. Partnerships between public and private organizations should be planned already in the early stages $[4,67,70]$, as well as promotion of alliances, in particular between emerging industries [71,72]. Finally, seeking stakeholders' approval and commitment (political, societal, business, etc.) is another important recommendation, which includes ensuring the strategic ambition is supported by long-term policies $[55,72,73]$ and that cooperation across organization boundaries is established for the implementation of SSC initiatives [74].

\subsection{Defining Assessment Criteria}

Still under the planning phase, cities should define the assessment criteria to be used in the monitoring and assessment of SSC initiatives. According to Caird and Hallett, developing effective approaches for city measurement is very challenging, requiring a clear definition of the evaluation process [75]. Therefore, the defining assessment criteria condition is achieved by: 3.1 define key performance indicators (KPIs) (what will be 
checked), 3.2 define assessment tools (how the KPIs will be checked), and 3.3 define performance evaluation plan (who will check the KPIs and when).

Regarding the definition of KPIs, the targets must be defined in order to monitor the progress of initiatives [72,74]. Huovila et al. [76] in their study provided a summary of indicators on SSC. According to the recommendations of the ITU-T Focus Group, Focus Group on Smart Sustainable Cities (TR on "Key performance indicators definitions for smart sustainable cities") at least six dimensions should be considered, namely, information and communications technologies, environmental sustainability, productivity, equity and social inclusion, quality of life, and physical infrastructure. That step is followed by the selection and use of compliance and monitoring and assessments tools to achieve the main evaluation goals. The literature presents a huge range of smart sustainable cities assessments [77], but a lack of standards. Some SSC assessment tools and frameworks are focused on sustainability indicators, others in emerging technologies; however, when assessing the SSC, both aspects should be integrated [64,76]. In addition, cities can use the Sustainable Development Goals indicators as a reference to create KPIs to monitor the progress of SSC initiatives. Finally, setting up a plan includes defining responsibilities (who) and the timeframe (when) of the performance evaluation to take place.

\subsection{Managing Policies}

Establishing supportive government policies and ensuring political will are key aspects of implementing smart sustainable city initiatives due to the current ineffectiveness of policies. The managing policies condition is achieved by conditions: 4.1 identify existing policies and 4.2 review, update, create, integrate, and evaluate policies. Identifying existing policies is the first step, due to the multiplicity of policies and programs in different levels of government (local, regional, national) [59,78-81] and to ensure alignment between them. Addressing sustainability challenges requires a holistic and cross-sector policy approach to ensure the balance between economic, social, and environmental aspects, and being a governance-related issue, requires the right instruments to ensure policy coherence [82]. Therefore, for creating policies, a multidisciplinary team should be involved to understand the context-related challenges [83]. Finally, the process of creating policies should not be centralised; the adoption of participatory governance paradigms (e.g., joint-up governance, network governance) as well as collaboration across government departments and agencies is recommended [84].

\subsection{Defining Management and Governance Arrangements}

Cities' lack of proper planning, strategy definition, monitoring and assessment practices can be a consequence of the lack of project management practices $[8,85]$. This condition is defined by conditions: 5.1 establish a governance model and 5.2 manage capacities. The governance model is defined by the clear definition of roles and responsibilities and may include the designation of a leader (also denoted as champion) to promote and supervise the SSC initiative $[28,71,74,81,86,87]$. One of the findings of the case analysis is the risk of discontinuity of initiatives in the next municipal administration. Therefore, it is important that the assignment of responsibilities is within the civil service to avoid transitions of political leadership resulting in the end of an initiative [88]. Considering that frequently the administrative structure of cities is organised in isolated silos (operational nodes), the governance arrangements should ensure internal coordination and cooperation within the city's agencies $[48,74,89,90]$. Enabling of information sharing and integration between municipal agencies is crucial for a collaborative governance [91].

Managing capacities is a transversal aspect for initiatives in the different sectors, including human resources management, infrastructure (urban resources) management and financial management. From an economic point of view, an important enabler is related to an effective management of urban resources [92], which aims to avoid waste and to maximise economic benefits. Other authors have called the sustainable management of resources as a Circular Economy [54,93] or Collaborative Consumption [93]. Ramaswami et al. suggested 
multisector synergies for resource efficiency [94]; the authors explained that cities must increase their efficient provision of resources, as citizens are increasing their consumption; however, this provision should not come from one single provider, and cities should create opportunities for systemic multisector interventions. Regarding the financial capacity, the high costs of urban infrastructure for SSC development (including both operational and maintenance) was strongly stressed by academics [17,66-68,95-97]. The lack of funding and the challenge of attracting investors are key issues [15,23,48,65-69]. In addition, authors have criticised the imbalance between investments regarding hard infrastructure (physical, hardware, sensors, systems) and soft infrastructure (capabilities) [64].

\subsection{Engaging with Stakeholders}

SSC is an interdisciplinary concept that connects different disciplines and multiple stakeholders. Engaging with stakeholders is achieved by the recommendations of: 6.1 engaging citizens, 6.2 engaging internal stakeholders and 6.3 engaging external stakeholders. Besides the social implications, engaging with stakeholders may tackle economic challenges by promoting innovative ecosystems and creating living and urban labs to help the development of smart sustainable cities initiatives, as reflected in the cases of Vienna and Curitiba. Urban labs have the potential to co-create value engaging users in research and development (R\&D) [98] and provide an infrastructure for knowledge exchange and learning between all these actors $[99,100]$. The use of crowdsourcing is also an alternative way to foster urban innovation as it helps to generate new ideas serving as an engagement platform $[65,71,101-104]$. Stakeholder collaboration can be internal (cross-sector) or external, resulting in partnerships and approaches such as the "triple helix model" (publicprivate-academia partnership) or even the "quadruple helix" (public, private, university and citizens) [6]. A model for stakeholder engagement was suggested by Ibrahim et al. [86].

In particular, the engagement with citizens can be facilitated by online tools but also in traditional offline initiatives, which requires creating mechanisms to allow citizen participation and co-creation besides defining a clear communication plan. Since public participation is a crucial aspect for the sustainable development of a city, it is important to understand the reasons for participation or non-participation of citizens in local initiatives [78]. In addition, authors have stated that smart sustainable city initiatives should be transparent $[17,48,94]$, make use of open government approaches $[48,71,105,106]$ and should empower and engage citizens with the design of (interactive) services [18,71]. These aspects are reflected in the case of Montevideo, in which the availability of open data facilitates interventions and applications systems initiated by citizens in a bottom-up approach. Engaging internal stakeholders can be also understood as cross-sector collaboration and can be facilitated using coordination mechanisms, requiring the establishment of horizontal structures, to foster collaboration. Strategy definition could facilitate the work between multiple stakeholders [72] and help create synergy among different city departments [71]. Engaging with external stakeholders relates to the establishment of partnerships to avoid isolated silos (structures), promoting cooperation and coordination between organizations. This requires a partnership overview, the definition of the legal framework and consideration for the strategic alignment. Furthermore, the use of formal / ad-hoc forums is recommended to map conflicts, and the adoption of techniques to prepare and provide training to city partners [72]. Finally, it is important to consider how to manage stakeholders and how to motivate them to "work collaboratively" in the development of long-term initiatives, as illustrated in the case of Gdansk, by developing methodologies and tools for creating real-time collaborative applications.

\subsection{Managing and Governing Data}

Another key finding relates to the importance of data for smart sustainable cities development. Therefore, managing and governing data is achieved by conditions: 7.1 ensure appropriate data management, 7.2 establish data governance strategy and 7.3 define security and data privacy policies. The need for data sharing across different systems was 
strongly stressed by the literature $[9,104,107]$. Nevertheless, there are some challenges to overcome to make efficient use of the data. Data management comprises some technical aspects in terms of collecting, normalising (modelling imperfect data), and processing data to transform it into knowledge. In addition, it includes ensuring real-time data analytics, and interoperability of systems that should be capable of aggregating information coming from several systems and devices, which is illustrated by the cases of Gdansk and Copenhagen. The lack of data quality can affect data-based decision making and, consequently, the performance of urban services [108].

Some scholars also stressed the urgency of an "enterprise data management" in the public sector [109], and the importance of observing roles and responsibilities related to data management [110]. In this sense, questions as to who owns the data, which data can be used, and who is responsible for ensuring data quality should be addressed under the data governance strategy. Data governance means defining which data should be used, when and by whom, defining who is the data owner, ensuring compliance with data protection regulations and data privacy policies. In this sense, Barcelona has defined a municipal government data model, in which there is a clear definition of roles and responsibilities, and the establishment of a Chief Data Officer (CDO) position. Moreover, as more and more systems are (or should be) connected, more data is exchanged, consequently increasing the need for ensuring systems' security and protecting sensitive data $[55,71,72,79,105,111,112]$. In our literature review, several scholars mentioned the risk of threats from hackers, viruses, and privacy violation. Analysing privacy from a different perspective, Bennati and Pournaras [111] stated that big data and IoT are usually "privacy-intrusive" resulting in the feeling of surveillance that could have a negative effect.

\subsection{Setting up the Infrastructure and Integration}

The implementation phase of smart sustainable city initiatives also involves the configuration of the technological infrastructure and integration with existing solutions and architecture. Thus, this condition is achieved by conditions: 8.1 implement the infrastructure of systems and devices and 8.2 ensure interoperability and systems integration. Concerning ICT, many academics have highlighted the complexity of ensuring connectivity, lack of operational integration, lack of systems interoperability, and data related issues. Disruptive technologies like big data through an IoT, and big data processing through AI bring emerging promises for a city's design and management [113]. Allam and Dhunny [112] mentioned several applications of AI that could benefit from the development of SSC, such as AI for education, environment, health care, policy, mobility and sustainability. Moreover, authors have mentioned the application of advanced ICT and developments in remote sensing, which allows the usage of satellite data for monitoring cities almost in real-time [48,114-118]. However, in order to benefit from the use of those emerging technologies, cities should have a robust infrastructure of systems and devices that are able to capture, process and spread data within different sources [71,97,119], and physical infrastructure integration-optical networks to support the communication of different data centres. Concerned with the importance of "connectivity", Zhang et al. [92] focused their work on the design of optical networks to support the communication of different data centres aiming to enhance network controllability, flexibility, and to reduce the cost of operational management, an aspect also addressed by the Bogotá case with connectivity deployment initiatives. In addition, it is important to use open sources, to facilitate the interoperability within systems and to avoid vendor locker. Some challenges related to this condition include technological obsolescence and the need for upgrading infrastructures $[15,23,66,68,93,98,107,120-122]$. Another aspect is the risk of vendor "lock-in" due to the use of proprietary software that makes the customer (in this case the city) dependent on the vendor or service provider $[8,68,120]$. 


\subsection{Delivering and Disseminating Initiatives}

After the initiative implementation and integration to the existing environment, this condition aims at delivering and communicating the new or updated solution or initiative to ensure its adoption. This condition is achieved through 9.1 establish good internal and external communication. During the validation process, one of the experts suggested that this phase should be focused on the "appropriation" of the solution, in order to obtain its benefits. Cities should communicate about the initiatives using different channels to ensure social inclusion. Furthermore, to deal with multiple stakeholders (including citizens), establishing good internal and external communication [85] and feedback channels [71] is necessary. Therefore, it is important to investigate the communication methods being used by cities and their effectiveness in the governance process of SSC initiatives [78]. To promote the initiatives in the Santiago case, exhibitions were established where companies, innovators, municipalities, universities, and SMEs participated to present their products and SC services.

\subsection{Managing Education and Users' Training}

The lack of capacity building, including a lack of investments in skills development, training, and education is one of the main identified barriers for the successful development and adoption of smart sustainable city initiatives. This condition is achieved through 10.1 manage education programs and 10.2 provide training for users. To ensure that capacity building occurs along with public sector innovation, cities should plan resources, including human resources and education programmes to implement sustainable initiatives. In addition, Yarime [104] highlights the need for creating capacity for data management. The lack of information technology (IT) knowledge is considered as a capacity issue, thus, it is a governance-related aspect. Besides the need of an operational IT workforce, scholars have described a lack of IT knowledge among public authorities and policy makers [123] for helping with digital transformation and identifying new ways to deliver urban services, as in the cases of Buenos Aires, Panama City, Tallin and Helsinki. Another benefit of providing users' training activities is to minimise the risk of a digital divide.

\subsection{Monitoring and Assessing Initiatives for Continuous Improvement}

The development of smart sustainable city initiatives requires continuous improvement by monitoring the progress of all phases, and collecting, and sharing information within their realisation. This condition is achieved by 11.1 performance assessment and 11.2 feedback analysis and knowledge creation. The performance assessment is based on the criteria defined in condition 3 (defining assessment criteria) of the planning phase. Considering the importance of citizens' engagement in SSC, they should be strongly involved also in the evaluation of the initiatives. Cities should have a dedicated team or organization responsible for the "monitoring" of SSC initiatives and they should ensure the use of compliance and assessments tools [124]. Good practice examples can be taken from the Barcelona and Vienna cases, as both cities have an organization responsible for smart sustainable city related initiatives and projects. Knowledge creation is also part of this condition, as the idea is to collect user feedback, and to document the lessons learnt from existing initiatives; however, it is worthy of mention that if the city makes use of feedback channels, then public administrations should be able to reply and attend to requests under a predefined service level agreement.

\section{Conclusions}

\subsection{Practical and Research Implications}

The first three steps of this research allowed for the identification of antecedents that may hinder or facilitate the development of SSC initiatives with a focus on the governance elements to ensure their long-term impact. The analysis of results suggests that a smart sustainable city is indeed a connection between the five dimensions, i.e., social, economic, environmental, governance and urban infrastructure, included in the conceptual framework 
proposed by Azambuja et al. [16] and discussed in Section 1.1. Therefore, all the aspects of SSC are connected and all dimensions should be balanced to reach sustainability. The mindset should be towards a "whole city" [74], since isolated initiatives can contribute, but long-term impacts would be maximised by addressing the strategic vision of a city together in order to became smarter and sustainable.

The fourth step of this research elaborated on the SSC governance dimension resulting in a roadmap describing 11 key governance conditions for developing strategies for smart sustainable city initiatives. The roadmap is divided into three main phases, moving from the planning phase, as a preliminary activity, to the implementation of initiatives, and finally to the adoption and evaluation phase. The roadmap can be used to guide initiatives in different levels of development and therefore can be initiated in any phase or condition, in a recurring way. Since the process of developing smart sustainable city initiatives follows a continuous and iterative approach, in each development loop the governance capacities are enlarged. This study also generated several insights for a future research agenda on SSC, which have been translated into actionable research-based practical recommendations that can possibly lead to improvements on smart sustainable city governance capacity as follows:

- Urban/Local planning: define city/initiative strategy, considering a shared vision with stakeholders to promote city attractiveness and competitiveness, accessibility, and social inclusion, as well as environmentally friendly initiatives.

- Adaptive governance: analyse current situation, adapt to the context, allowing for flexibility and responsiveness to local challenges and needs.

- Leadership and proactive behaviour: define a dedicated organization, department, or person for promoting and supervising initiatives, and ensure urban proactiveness for service provision.

- Citizen empowerment: provide interactive and participatory services, promoting co-production, co-creation, and bottom-up approaches.

- Stakeholders' engagement: ensure internal (cross-sector) and external collaboration, including public-private partnerships enabled by information and knowledge sharing and appropriate communication channels.

- Resources: appropriate planning and management of infrastructure, financial and human capacity in a sustainable way.

- Data Governance: ensure appropriate management of data, with focus on the definition of data quality, data sharing and data privacy policies to enable data-driven decision-making and availability of real-time data.

- Governance arrangements: ensure clear definition of roles and responsibilities towards collaborative decision-making and participatory governance models.

- Institutional/organizational framework: establish supportive government policies, ensure political will, synergy among different city departments, policy alignment across government levels, internal coordination and align and manage conflicts of interests.

- Regulatory framework: establish a comprehensive regulatory framework, including norms, laws and directions for integrated solutions and ensure data protection, privacy, and security.

- Open Government and social responsibility: ensure transparency and openness and increase citizen awareness.

- Digital skills: strengthen access to training and education programs to increase IT knowledge among city planners and operational capacity, including IT skills, artificial intelligence, big data, networks, and security.

- Monitoring and evaluation: define KPIs and ensure the use of compliance and monitoring/assessments tools.

Thus, this study has the potential to help different stakeholders, such as decision makers, public administrators, and practitioners in the identification of sustainability challenges and governance aspects to be considered when developing SSC initiatives that can generate long-term impact. 


\subsection{Limitations and Future Research Directions}

Some limitations of this study should be acknowledged. First, the data collection for the development of the roadmap was performed in May 2019, including the systematic literature review and the analysis of the initiatives; however, for the systematic literature review, the authors verified a sample of $20 \%$ additional papers published up until October 2021 and no additional drivers or barriers were found, meaning that the study reached data saturation [125]. Thus, we may argue that the timeframe for the data collection does not affect the results of this research, confirming its relevance. Second, the authors used content analysis and followed an existing conceptual framework to guide the identification and classification of the phases and key conditions of the roadmap to guide the development of SSC, covering five main domains; however, a different perspective and the adoption of other conceptual models could indicate a slightly different set of conditions and smart sustainable city governance guidelines. In addition, as sustainable dimensions are often interconnected, some sustainability challenges and conditions identified in the roadmap could also be represented by overlapping categories or phases and they may vary according to different contexts.

We have also identified some aspects that should be further investigated. For example, some authors argue that the ineffectiveness of policies may hinder SSC development and in other contexts the barriers consist of the multiplicity of policies across different public levels, e.g., local, regional, and national. We highlight that the implementation of the roadmap for developing smart sustainable city initiatives should be aligned with existing smart city strategies or subnational strategies to ensure their institutionalisation. Therefore, defining the institutional framework that legitimises the development of smart sustainable cities, ensuring policy alignment across government levels, will improve their sustainability in the long-term. Another important contribution is that investments in emerging technologies should be accompanied by capacity building, since the lack of investments in skills development, training, and education is one of the main identified challenges. Governance capacity is often neglected by public sector innovation, despite being a crucial element to achieve sustainable benefits. Cities should invest in human resources and developing digital skills, for instance by supporting education programmes to implement sustainable initiatives. Furthermore, it is important to investigate if the universities are ready to address the transformation occurring in cities [20]. Thus, a next step of this research consists of using the roadmap as a basis for developing curricula for tackling the required competencies for smart cities and sustainable development. Finally, this research provides the basis for common understanding and action, by revealing the main phases and conditions for developing smart sustainable city initiatives and guidelines for strengthening the governance capacity needed to address the sustainability challenges, and to ensure long-term impact of the solutions. Additionally, as a design-science-based research, the innovation processes (conditions) continue to evolve once the roadmap (artefact) is evaluated in practice as part of the design cycle [43], therefore, multiple case studies are foreseen, in which the roadmap will be used for building and evaluating smart city initiatives, which may generate additional insights about local governance and sustainability challenges.

Author Contributions: Conceptualisation, G.V.P. and L.S.d.A.; methodology, G.V.P. and L.S.d.A.; validation, L.S.d.A.; formal analysis, G.V.P.; data curation, L.S.d.A.; writing—original draft preparation, L.S.d.A.; writing-review and editing, G.V.P. and L.S.d.A.; visualisation, G.V.P.; supervision, G.V.P.; project administration, G.V.P.; funding acquisition, G.V.P. All authors have read and agreed to the published version of the manuscript.

Funding: This research was funded by the European Commission within the ERASMUS+ Programme in the context of the project CAP4CITY (www.cap4city.eu), grant number 598273- EPP-1-2018-1-ATEPPKA2-CBHE-JP. Open Access Funding by the University for Continuing Education Krems.

Data Availability Statement: The description of the cases will be available by the end of the Erasmus+ CAP4CITY project in the following link https://www.cap4city.eu/home/outcomes. 
Acknowledgments: The authors would like to acknowledge the feedback and recommendations provided by the CAP4CITY partners, the additional support provided by Robert Krimmer, RalfMartin Soe and Lucy Temple and the valuable comments provided by five anonymous reviewers.

Conflicts of Interest: The authors declare no conflict of interest.

\section{References}

1. Pereira, G.V.; Estevez, E.; Krimmer, R.; Janssen, M.; Janowski, T. Towards a Smart Sustainable City Roadmap. In Proceedings of the 20th Annual International Conference on Digital Government Research, Dubai, United Arab Emirates, 18-20 June 2019; pp. 527-528.

2. Mora, L.; Bolici, R.; Deakin, M. The First Two Decades of Smart-City Research: A Bibliometric Analysis. J. Urban Technol. 2017, 24, 3-27. [CrossRef]

3. Bibri, S.E.; Krogstie, J. Smart sustainable cities of the future: An extensive interdisciplinary literature review. Sustain. Cities Soc. 2017, 31, 183-212. [CrossRef]

4. Ismagilova, E.; Hughes, L.; Dwivedi, Y.K.; Raman, K.R. Smart cities: Advances in research-An information systems perspective. Int. J. Inf. Manag. 2019, 47, 88-100. [CrossRef]

5. Lara, A.P.; Da Costa, E.M.; Furlani, T.Z.; Yigitcanlar, T. Smartness that matters: Towards a comprehensive and human-centred characterisation of smart cities. J. Open Innov. Technol. Mark. Complex. 2016, 2, 8-13. [CrossRef]

6. Martin, C.; Evans, J.; Karvonen, A.; Paskaleva, K.; Yang, D.; Linjordet, T. Smart-sustainability: A new urban fix? Sustain. Cities Soc. 2019, 45, 640-648. [CrossRef]

7. Sarv, L.; Soe, R.-M. Transition towards Smart City: The Case of Tallinn. Sustainability 2021, 13, 4143. [CrossRef]

8. Yigitcanlar, T.; Kamruzzaman, M.; Foth, M.; Sabatini-Marques, J.; Da-Costa, E.; Ioppolo, G. Can cities become smart without being sustainable? A systematic review of the literature. Sustain. Cities Soc. 2019, 45, 348-365. [CrossRef]

9. Bibri, S.E. Smart Sustainable Cities of the Future; Springer: Berlin/Heidelberg, Germany, 2018; Volume 38.

10. Yigitcanlar, T.; Kamruzzaman, M.; Buys, L.; Ioppolo, G.; Sabatini-Marques, J.; da Costa, E.M.; Yun, J.J. Understanding 'smart cities': Intertwining development drivers with desired outcomes in a multidimensional framework. Cities 2018, 81, 145-160. [CrossRef]

11. Giffinger, R.; Fertner, C.; Kramar, H.; Kalasek, R.; Pichler-Milanovic, N.; Meijers, E. Smart Cities: Ranking of European Mid-Sized Cities; IGI Global: Hershey, PA, USA, 2007.

12. Estevez, E.; Janowski, T. Electronic Governance for Sustainable Development-Conceptual framework and state of research. Gov. Inf. Q. 2013, 30, S94-S109. [CrossRef]

13. Phaal, R.; Farrukh, C.J.; Probert, D.R. Technology roadmapping-A planning framework for evolution and revolution. Technol. Forecast. Soc. Chang. 2004, 71, 5-26. [CrossRef]

14. Bibri, S.E.; Krogstie, J. On the social shaping dimensions of smart sustainable cities: A study in science, technology, and society. Sustain. Cities Soc. 2017, 29, 219-246. [CrossRef]

15. Estevez, E.; Lopes, N.V.; Janowski, T. Smart Sustainable Cities: Reconnaissance Study; United Nations University Operating Unit on Policy-Driven Electronic Governance: Guimarães, Portugal, 2016.

16. De Azambuja, L.S.; Pereira, G.V.; Krimmer, R. Clearing the existing fog over the smart sustainable city concept. In Proceedings of the 13th International Conference on Theory and Practice of Electronic Governance; ACM: New York, NY, USA, 2020; pp. 628-637. [CrossRef]

17. Chourabi, H.; Nam, T.; Walker, S.; Gil-Garcia, J.R.; Mellouli, S.; Nahon, K.; Pardo, T.A.; Scholl, H.J. Understanding smart cities: An integrative framework. In Proceedings of the 2012 45th Hawaii International Conference on System Science, Maui, HI, USA, 4-7 January 2012; pp. 2289-2297.

18. Alawadhi, S.; Aldama-Nalda, A.; Chourabi, H.; Gil-Garcia, J.R.; Leung, S.; Mellouli, S.; Nam, T.; Pardo, T.A.; Scholl, H.J.; Walker, S. Building Understanding of Smart City Initiatives. In Lecture Notes in Computer Science; Springer Science and Business Media LLC: Berlin/Heidelberg, Germany, 2012; Volume 7443, pp. 40-53.

19. Al-Nasrawi, S.; El-Zaart, A.; Adams, C. Assessing smartness of smart sustainable cities: A comparative analysis. In Proceedings of the 2017 Sensors Networks Smart and Emerging Technologies (SENSET), Beiriut, Lebanon, 12-14 September 2017; pp. 1-4. [CrossRef]

20. Grimaldi, D.; Fernandez, V. The alignment of University curricula with the building of a Smart City: A case study from Barcelona. Technol. Forecast. Soc. Chang. 2017, 123, 298-306. [CrossRef]

21. Baraniewicz-Kotasińska, S. Smart city. Four approaches to the concept of understanding. Urban Res. Pract. 2020, 1-24. [CrossRef]

22. Guedes, A.L.A.; Alvarenga, J.C.; Goulart, M.D.S.S.; Rodriguez, M.V.R.Y.; Soares, C.A.P. Smart Cities: The Main Drivers for Increasing the Intelligence of Cities. Sustainability 2018, 10, 3121. [CrossRef]

23. Kramers, A.; Wangel, J.; Ahlsen, M. Governing the Smart Sustainable City: The case of Stockholm Royal Seaport. In Proceedings of the ICT for Sustainability 2016; Atlantis Press: Paris, France, 2016; pp. 99-108.

24. Alonso, R.G.; Castro, S.L.-D. Technology Helps, People Make: A Smart City Governance Framework Grounded in Deliberative Democracy. In Smarter as the New Urban Agenda; Springer Science and Business Media LLC: Berlin/Heidelberg, Germany, 2016; pp. $333-347$.

25. Albino, V.; Berardi, U.; Dangelico, R.M. Smart Cities: Definitions, Dimensions, Performance, and Initiatives. J. Urban Technol. 2015, 22, 3-21. [CrossRef]

26. Bergh, J.V.d.; Viaene, S. Key Challenges for the Smart City: Turning Ambition into Reality. In Proceedings of the 201548 th Hawaii International Conference on System Sciences, Manhattan, NY, USA, 5-8 January 2015; pp. 2385-2394. [CrossRef] 
27. Janowski, T.; Estevez, E.; Baguma, R. Platform governance for sustainable development: Reshaping citizen-administration relationships in the digital age. Gov. Inf. Q. 2018, 35, S1-S16. [CrossRef]

28. van Winden, W. Urban governance in the knowledge-based economy: Challenges for different city types. Innov. Manag. Policy Pract. 2008, 10, 197-210. [CrossRef]

29. Pereira, G.V.; Parycek, P.; Falco, E.; Kleinhans, R. Smart governance in the context of smart cities: A literature review. Inf. Polity 2018, 23, 143-162. [CrossRef]

30. Phaal, R.; Farrukh, C.; Probert, D. Characterisation of Technology Roadmaps: Purpose and Format. Picmet 2001, 2, 367-374. [CrossRef]

31. Ibrahim, M.; Adams, C.; El-Zaart, A. Smart Sustainable Cities: A New Perspective on Transformation, Roadmap and Framework Concepts. In Proceedings of the Fifth International Conference on Smart Cities, Systems, Devices and Technologies, Valencia, Spain, 22-26 May 2016; pp. 1-8.

32. Lee, J.H.; Phaal, R.; Lee, S.-H. An integrated service-device-technology roadmap for smart city development. Technol. Forecast. Soc. Chang. 2013, 80, 286-306. [CrossRef]

33. EPIC Consortium. D6.3 EPIC Roadmap for Smart Cities; EPIC Consortium: 2013. Available online: https://www.scribd.com/ document/369066948/EPIC-Roadmap-for-Smart-Cities (accessed on 19 November 2021).

34. ITU-T FG-SSC. Smart Sustainable Cities: A Guide for City Leaders; FG-SSC: Geneva, Switzerland, 2015.

35. Ibrahim, M.; El-Zaart, A.; Adams, C. Smart sustainable cities roadmap: Readiness for transformation towards urban sustainability. Sustain. Cities Soc. 2018, 37, 530-540. [CrossRef]

36. Taveres-Cachat, E.; Grynning, S.; Thomsen, J.; Selkowitz, S. Responsive building envelope concepts in zero emission neighborhoods and smart cities-A roadmap to implementation. Build. Environ. 2019, 149, 446-457. [CrossRef]

37. Iamtrakul, P.; Klaylee, J.; Ruengratanaumporn, I. Participatory Planning Approach towards Smart Sustainable City Development. Proc. Int. Struct. Eng. Constr. 2021, 8, 11. [CrossRef]

38. Szetey, K.; Moallemi, E.A.; Ashton, E.; Butcher, M.; Sprunt, B.; Bryan, B.A. Participatory planning for local sustainability guided by the Sustainable Development Goals. Ecol. Soc. 2021, 26. [CrossRef]

39. Bibri, S.E.; Krogstie, J. A Novel Model for Data-Driven Smart Sustainable Cities of the Future: A Strategic Roadmap to Transformational Change in the Era of Big Data. Futur. Cities Environ. 2021, 7, 1-25. [CrossRef]

40. Duvier, C.; Anand, P.; Oltean-Dumbrava, C. Data quality and governance in a UK social housing initiative: Implications for smart sustainable cities. Sustain. Cities Soc. 2018, 39, 358-365. [CrossRef]

41. Linkov, I.; Trump, B.D.; Poinsatte-Jones, K.; Florin, M.-V. Governance Strategies for a Sustainable Digital World. Sustainability 2018, 10, 440. [CrossRef]

42. Hevner, A.R.; March, S.T.; Park, J.; Ram, S. Design Science in Information Systems Research. MIS Q. 2004, 28, 75. [CrossRef]

43. Hevner Alan, R. A Three Cycle View of Design Science Research. Scand. J. Inf. Syst. 2007, 19, 87-92.

44. Page, M.J.; McKenzie, J.E.; Bossuyt, P.M.; Boutron, I.; Hoffmann, T.C.; Mulrow, C.D.; Shamseer, L.; Tetzlaff, J.M.; Akl, E.A.; Brennan, S.E.; et al. The PRISMA 2020 statement: An updated guideline for reporting systematic reviews. PLoS Med. 2021, 18, e1003583. [CrossRef]

45. Wolfswinkel, J.F.; Furtmueller-Ettinger, E.; Wilderom, C.P. Using grounded theory as a method for rigorously reviewing literature Eur. J. Inf. Syst. 2013, 22, 45-55. [CrossRef]

46. Webster, J.; Watson, R.T. Analyzing the Past to Prepare for the Future: Writing a Literature Review. MIS Q. 2002, 26, xiii-xxiii.viii.

47. De Azambuja, L.S. Drivers and Barriers for the Development of Smart Sustainable Cities: A Systematic Literature Review. In Proceedings of the 14th International Conference on Theory and Practice of Electronic Governance (ICEGOV 2021), Athens, Greece, 6-8 October 2021. [CrossRef]

48. Aina, Y.A. Achieving smart sustainable cities with GeoICT support: The Saudi evolving smart cities. Cities 2017, 71, 49-58. [CrossRef]

49. Bradburn, N.M.; Sudman, S.; Wansink, B. Asking Questions That Evaluate Performance. In Asking Questions: The Definitive Guide to Questionnaire Design; John Wiley \& Sons: Hoboken, NJ, USA, 2004; pp. 213-242.

50. Axelsson, K.; Granath, M. Stakeholders' stake and relation to smartness in smart city development: Insights from a Swedish city planning project. Gov. Inf. Q. 2018, 35, 693-702. [CrossRef]

51. Glasmeier, A.K.; Nebiolo, M. Thinking about Smart Cities: The Travels of a Policy Idea that Promises a Great Deal, but So Far Has Delivered Modest Results. Sustainability 2016, 8, 1122. [CrossRef]

52. Macke, J.; Casagrande, R.M.; Sarate, J.A.R.; Silva, K. Smart city and quality of life: Citizens' perception in a Brazilian case study. J. Clean. Prod. 2018, 182, 717-726. [CrossRef]

53. Adapa, S. Indian smart cities and cleaner production initiatives-Integrated framework and recommendations. J. Clean. Prod. 2018, 172, 3351-3366. [CrossRef]

54. Barns, S. Smart cities and urban data platforms: Designing interfaces for smart governance. City Cult. Soc. 2018, 12, 5-12. [CrossRef]

55. Fernandez-Anez, V.; Fernández-Güell, J.M.; Giffinger, R. Smart City implementation and discourses: An integrated conceptual model. The case of Vienna. Cities 2018, 78, 4-16. [CrossRef]

56. Grossi, G.; Pianezzi, D. Smart cities: Utopia or neoliberal ideology? Cities 2017, 69, 79-85. [CrossRef]

57. Kummitha, R.K.R.; Crutzen, N. How do we understand smart cities? An evolutionary perspective. Cities 2017, 67, 43-52. [CrossRef]

58. Lopes, I.M.; Oliveira, P. Can a small city be considered a smart city? Procedia Comput. Sci. 2017, 121, 617-624. [CrossRef]

59. Praharaj, S.; Han, J.H.; Hawken, S. Urban innovation through policy integration: Critical perspectives from 100 smart cities mission in India. City Cult. Soc. 2018, 12, 35-43. [CrossRef] 
60. Höjer, M.; Wangel, J. Smart Sustainable Cities: Definition and Challenges. Adv. Intell. Syst. Comput. 2014, 310, 333-349. [CrossRef]

61. Park, K. A Risk Management Model for Sustainable Smart City. Int. J. Adv. Sci. Technol. 2018, 110, 23-32. [CrossRef]

62. Ullah, F.; Qayyum, S.; Thaheem, M.J.; Al-Turjman, F.; Sepasgozar, S.M. Risk management in sustainable smart cities governance: A TOE framework. Technol. Forecast. Soc. Chang. 2021, 167, 120743. [CrossRef]

63. Pereira, G.V.; Wimmer, M.; Ronzhyn, A. Research needs for disruptive technologies in smart cities. In Proceedings of the 13th International Conference on Theory and Practice of Electronic Governance; ACM: New York, NY, USA, 2020; pp. 620-627.

64. Ahvenniemi, H.; Huovila, A.; Pinto-Seppä, I.; Airaksinen, M. What are the differences between sustainable and smart cities? Cities 2017, 60, 234-245. [CrossRef]

65. Angelidou, M.; Psaltoglou, A.; Komninos, N.; Kakderi, C.; Tsarchopoulos, P.; Panori, A. Enhancing sustainable urban development through smart city applications. J. Sci. Technol. Policy Manag. 2018, 9, 146-169. [CrossRef]

66. Ibrahim, M.; Al-Nasrawi, S.; El-Zaart, A.; Adams, C. Challenges Facing E-Government and Smart Sustainable City: An Arab Region Perspective. In Proceedings of the European Conference on e-Government, ECEG, Portsmouth, UK, 18-19 June 2015; pp. 396-402.

67. Ibrahim, M.; El-Zaart, A.; Adams, C. Paving the way to Smart Sustainable Cities: Transformation Models and Challenges. J. Inf. Syst. Technol. Manag. 2016, 12, 559-576. [CrossRef]

68. Silva, B.N.; Khan, M.; Han, K. Towards sustainable smart cities: A review of trends, architectures, components, and open challenges in smart cities. Sustain. Cities Soc. 2018, 38, 697-713. [CrossRef]

69. Yadav, G.; Mangla, S.K.; Luthra, S.; Rai, D.P. Developing a sustainable smart city framework for developing economies: An Indian context. Sustain. Cities Soc. 2019, 47, 101462. [CrossRef]

70. Koppenjan, J.F.M.; Enserink, B. Public-Private Partnerships in Urban Infrastructures: Reconciling Private Sector Participation and Sustainability. Public Adm. Rev. 2009, 69, 284-296. [CrossRef]

71. Lee, J.H.; Hancock, M.G.; Hu, M.-C. Towards an effective framework for building smart cities: Lessons from Seoul and San Francisco. Technol. Forecast. Soc. Chang. 2014, 89, 80-99. [CrossRef]

72. Keshvardoost, S.; Renukappa, S.; Suresh, S. Developments of Policies Related to Smart Cities: A Critical Review. In Proceedings of the 2018 IEEE/ACM International Conference on Utility and Cloud Computing Companion (UCC Companion), Zurich, Switzerland, 17-20 December 2018; pp. 370-375.

73. Bolívar, M.P.R.; Meijer, A.J. Smart Governance: Using a Literature Review and Empirical Analysis to Build a Research Model. Soc. Sci. Comput. Rev. 2016, 34, 673-692. [CrossRef]

74. Brorström, S.; Argento, D.; Grossi, G.; Thomasson, A.; Almqvist, R. Translating sustainable and smart city strategies into performance measurement systems. Public Money Manag. 2018, 38, 193-202. [CrossRef]

75. Caird, S.P.; Hallett, S.H. Towards evaluation design for smart city development. J. Urban Des. 2019, 24, 188-209. [CrossRef]

76. Huovila, A.; Bosch, P.; Airaksinen, M. Comparative analysis of standardized indicators for Smart sustainable cities: What indicators and standards to use and when? Cities 2019, 89, 141-153. [CrossRef]

77. Chang, D.L.; Marques, J.S.; Da Costa, E.M.; Selig, P.M.; Yigitcanlar, T. Knowledge-based, smart and sustainable cities: A provocation for a conceptual framework. J. Open Innov. Technol. Mark. Complex. 2018, 4, 5. [CrossRef]

78. Bednarska-Olejniczak, D.; Olejniczak, J.; Svobodová, L. Towards a Smart and Sustainable City with the Involvement of Public Participation-The Case of Wroclaw. Sustainability 2019, 11, 332. [CrossRef]

79. Caragliu, A.; Del Bo, C.F. Smart innovative cities: The impact of Smart City policies on urban innovation. Technol. Forecast. Soc. Chang. 2019, 142, 373-383. [CrossRef]

80. Nam, T.; Pardo, T.A. Smart City as Urban Innovation: Focusing on Management, Policy, and Context. In ICEGOV2011, September 26-28; Association for Computing Machinery: Tallinn, Estonia, 2011.

81. Vilajosana, I.; Llosa, J.; Martinez, B.; Domingo-Prieto, M.; Angles, A.; Vilajosana, X. Bootstrapping smart cities through a self-sustainable model based on big data flows. IEEE Commun. Mag. 2013, 51, 128-134. [CrossRef]

82. EU. Communication from the Commission to the European Parliament, the Council, the European Economic and Social Committee and the Committee of the Regions: Next Steps for a Sustainable European Future; EU: Brussels, Belgium, 2016.

83. Kovacic, Z. Governing informality through representation: Examples from slum policies in Brazil and South Africa. Cities 2018, 102122. [CrossRef]

84. Alawadhi, S.; Scholl, H.J. (Eds.) Smart Governance: A Cross-Case Analysis of Smart City Initiatives. In Proceedings of the 2016 49th Hawaii International Conference on System Sciences (HICSS), Koloa, HI, USA, 5-8 January 2016.

85. Joshi, S.; Saxena, S.; Godbole, T. Shreya Developing Smart Cities: An Integrated Framework. Procedia Comput. Sci. 2016, 93, 902-909. [CrossRef]

86. Ibrahim, M.; El-Zaart, A.; Adams, C. Stakeholders Engagement in Smart Sustainable Cities: A Proposed Model. In Proceedings of the 2017 International Conference on Computer and Applications (ICCA), Doha, United Arab Emirates, 6-7 September 2017; pp. 342-347. [CrossRef]

87. Kramers, A.; Höjer, M.; Wangel, J. Planning for smart sustainable cities: Decisions in the planning process and actor networks. In ICT for Sustainability 2014 (ICT4S-14); Atlantis Press: Amsterdam, The Netherlands, 2014.

88. Ben Letaifa, S. How to strategize smart cities: Revealing the SMART model. J. Bus. Res. 2015, 68, 1414-1419. [CrossRef]

89. Kogan, N.; Lee, K.J. Exploratory Research on the Success Factors and Challenges of Smart City Projects. Asia Pac. J. Inf. Syst. 2014, 24, 141-189. [CrossRef] 
90. Tachizawa, E.M.; Alvarez-Gil, M.J.; Montes-Sancho, M.J. How "smart cities" will change supply chain management. Supply Chain Manag. Int. J. 2015, 20, 237-248. [CrossRef]

91. Pereira, G.V.; Cunha, M.A.; Lampoltshammer, T.J.; Parycek, P.; Testa, M.G. Increasing collaboration and participation in smart city governance: A cross-case analysis of smart city initiatives. Inf. Technol. Dev. 2017, 23, 526-553. [CrossRef]

92. Zhang, X.; Guo, L.; Hou, W.; Ning, Z.; Zhang, Q.; Li, H. An efficient data delivery and scheduling scheme for smart and sustainable cities. J. Clean. Prod. 2019, 215, 497-513. [CrossRef]

93. Esmaeilian, B.; Wang, B.; Lewis, K.; Duarte, F.; Ratti, C.; Behdad, S. The future of waste management in smart and sustainable cities: A review and concept paper. Waste Manag. 2018, 81, 177-195. [CrossRef]

94. Ramaswami, A.; Russell, A.G.; Culligan, P.J.; Sharma, K.R.; Kumar, E. Meta-principles for developing smart, sustainable, and healthy cities. Science 2016, 352, 940-943. [CrossRef]

95. Honarvar, A.R.; Sami, A. Towards Sustainable Smart City by Particulate Matter Prediction Using Urban Big Data, Excluding Expensive Air Pollution Infrastructures. Big Data Res. 2019, 17, 56-65. [CrossRef]

96. Monzon, A. Smart Cities Concept and Challenges. In Proceedings of the 2015 International Conference on Smart Cities and Green ICT Systems (SMARTGREENS), Lisbon, Portugal, 20-22 May 2015; pp. 17-31.

97. Rana, N.P.; Luthra, S.; Mangla, S.K.; Islam, R.; Roderick, S.; Dwivedi, Y.K. Barriers to the Development of Smart Cities in Indian Context. Inf. Syst. Front. 2018, 21, 503-525. [CrossRef]

98. Komninos, N.; Pallot, M.; Schaffers, H. Special Issue on Smart Cities and the Future Internet in Europe. J. Knowl. Econ. 2013, 4, 119-134. [CrossRef]

99. Meijer, A.; Bolívar, M.P.R. Governing the smart city: A review of the literature on smart urban governance. Int. Rev. Adm. Sci. 2015, 82, 392-408. [CrossRef]

100. Soe, R.-M.; de Azambuja, L.S.; Toiskallio, K.; Nieminen, M.; Batty, M. Institutionalising smart city research and innovation: From fuzzy definitions to real-life experiments. Urban Res. Pract. 2021, 00, 1-43. [CrossRef]

101. Niforatos, E.; Vourvopoulos, A.; Langheinrich, M. Understanding the potential of human-machine crowdsourcing for weather data. Int. J. Hum.-Comput. Stud. 2017, 102, 54-68. [CrossRef]

102. Schuurman, D.; Baccarne, B.; De Marez, L. Smart Ideas for Smart Cities: Investigating Crowdsourcing for Generating and Selecting Ideas for ICT Innovation in a City Context. J. Theor. Appl. Electron. Commer. Res. 2012, 7, 11-12. [CrossRef]

103. Vakali, A.; Dematis, I.; Tolikas, A. Vol4All: A Volunteering Platform to Drive Innovation and Citizens Empowerment. In Proceedings of the 26th International Conference on Compiler Construction, Austin, TX, USA, 5-6 February 2017; Volume 4, pp. 1173-1178.

104. Yarime, M. Facilitating data-intensive approaches to innovation for sustainability: Opportunities and challenges in building smart cities. Sustain. Sci. 2017, 12, 881-885. [CrossRef]

105. Khan, Z.; Pervez, Z.; Abbasi, A.G. Towards a secure service provisioning framework in a Smart city environment. Futur. Gener. Comput. Syst. 2017, 77, 112-135. [CrossRef]

106. Meijer, A.; Rodríguez Bolívar, M.P. Governing the Smart City: Scaling-Up the Search for Socio-Techno Synergy. EGPA Annu. Conf. 2013, 2013, 1-13.

107. Yeh, H. The effects of successful ICT-based smart city services: From citizens' perspectives. Gov. Inf. Q. 2017, 34, 556-565. [CrossRef]

108. Ben Sta, H. Quality and the efficiency of data in "Smart-Cities". Futur. Gener. Comput. Syst. 2017, 74, 409-416. [CrossRef]

109. Harrison, T.; Pardo, T.; Gascó-Hernandez, M.; Canestraro, D. The Salience and Urgency of Enterprise Data Management in the Public Sector. In Proceedings of the 50th Hawaii International Conference on System Sciences (2017), Hilton Waikoloa Village, HI, USA, 4-7 January 2017; pp. 2246-2255.

110. Vilminko-Heikkinen, R.; Pekkola, S. Changes in roles, responsibilities and ownership in organizing master data management. Int J. Inf. Manag. 2019, 47, 76-87. [CrossRef]

111. Bennati, S.; Pournaras, E. Privacy-enhancing aggregation of Internet of Things data via sensors grouping. Sustain. Cities Soc. 2018, 39, 387-400. [CrossRef]

112. Allam, Z.; Dhunny, Z.A. On big data, artificial intelligence and smart cities. Cities 2019, 89, 80-91. [CrossRef]

113. Costin, A.; Eastman, C. Need for Interoperability to Enable Seamless Information Exchanges in Smart and Sustainable Urban Systems. J. Comput. Civ. Eng. 2019, 33, 04019008. [CrossRef]

114. Bibri, S.E.; Krogstie, J. ICT of the new wave of computing for sustainable urban forms: Their big data and context-aware augmented typologies and design concepts. Sustain. Cities Soc. 2017, 32, 449-474. [CrossRef]

115. Rao, R.G.S.; Rayaguru, N.K.; Renganathan, N.G.; Thakur, S.K. City-Scale Spatial Data Infrastructure for Solar Photovoltaic Energy Generation Assessment. Int. J. Eng. Technol. 2018, 7, 4-7. [CrossRef]

116. Jat, M.K.; Saxena, A. Sustainable Urban Growth using Geoinformatics and CA based Modelling. In Proceedings of the 11th International Conference on Theory and Practice of Electronic Governance, Galway, Ireland, 4-6 April 2018; pp. 499-508.

117. Mokoena, B.T.; Musakwa, W.; Moyo, T. Developing the Well-Located Land Index to Establish Smart Human Settlements for the Ekurhuleni Municipality, South Africa. In Lecture Notes in Geoinformation and Cartography; Springer: Berlin/Heidelberg, Germany, 2017; pp. 95-112.

118. Song, Y.; Wang, X.; Tan, Y.; Wu, P.; Sutrisna, M.; Cheng, J.C.P.; Hampson, K. Trends and Opportunities of BIM-GIS Integration in the Architecture, Engineering and Construction Industry: A Review from a Spatio-Temporal Statistical Perspective. ISPRS Int. J. Geo-Inf. 2017, 6, 397. [CrossRef] 
119. Corbett, J.; Mellouli, S. Winning the SDG battle in cities: How an integrated information ecosystem can contribute to the achievement of the 2030 sustainable development goals. Inf. Syst. J. 2017, 27, 427-461. [CrossRef]

120. O'Dwyer, E.; Pan, I.; Acha, S.; Shah, N. Smart energy systems for sustainable smart cities: Current developments, trends and future directions. Appl. Energy 2019, 237, 581-597. [CrossRef]

121. Ringenson, T.; Eriksson, E.; Rivera, M.B.; Wangel, J. The Limits of the Smart Sustainable City. In Proceedings of the 2017 Workshop on Computing Within Limits, Santa Barbara, CA, USA, 22-24 June 2017. [CrossRef]

122. Sodhro, A.H.; Pirbhulal, S.; Luo, Z.; de Albuquerque, V.H.C. Towards an optimal resource management for IoT based Green and sustainable smart cities. J. Clean. Prod. 2019, 220, 1167-1179. [CrossRef]

123. Scuotto, V.; Ferraris, A.; Bresciani, S. Internet of Things: Applications and challenges in smart cities. A case study of IBM smart city projects. Bus. Process Manag. J. 2016, 22, 357-367. [CrossRef]

124. Garau, C.; Pavan, V.M. Evaluating Urban Quality: Indicators and Assessment Tools for Smart Sustainable Cities. Sustainability 2018, 10, 575. [CrossRef]

125. Saunders, B.; Sim, J.; Kingstone, T.; Baker, S.; Waterfield, J.; Bartlam, B.; Burroughs, H.; Jinks, C. Saturation in qualitative research: Exploring its conceptualization and operationalization. Qual. Quant. 2018, 52, 1893-1907. [CrossRef] [PubMed] 